\title{
THE PERSPECTIVES OF EUROPEAN SOCIETY AND THE EUROPEAN COOPERATIVE AS A FORM OF ENTREPRENEURSHIP IN THE CONTEXT OF THE IMPACT OF EUROPEAN ECONOMIC POLICY
}

\author{
Tomáš PERÁČEK, PhD
}

Comenius University in Bratislava, Faculty of Management, Slovakia

peracek2@uniba.sk

\begin{abstract}
The impact of European economic policy is felt in all areas of the existence of individual Member States. Its economic area is not an exception. In the context of entrepreneurship, the impact of European economic policy has also been reflected in the introduction of new legal forms of entrepreneurship. The primary concern is a European society and a European cooperative whose legislation has become part of the national legal order under European Union regulations. This article focuses on examining these legal forms of entrepreneurship. The main objective of the article is to comprehensively analyse the legislative aspects of European society and the European cooperative and to examine their legal regulation and status in the legal system of the Slovak Republic, especially using critical analysis and other scientific methods, we are looking for answers to selected application problems from practice. As part of the investigation we also use scientific and doctrinal interpretation, Slovak and foreign professional literature and case law Comprehensive legal examination of European society and European cooperative in the Slovak Republic is the main objective of this contribution, which belongs to the field of commercial law with certain overlaps into economics and entrepreneurship.
\end{abstract}

Keywords: European Policy, European Cooperative Society, European Society, Entrepreneurship in the European Union.

\section{Introduction}

The expansion of the European Economic Area as a result of the enlargement of the European Union included new Member States and has created new business opportunities for entrepreneurs, particularly in the area of new legal forms of entrepreneurship. In professional circles we encounter relatively little known terms "European joint stock company" and "European cooperative". A European joint-stock company is considered to be a transnational European counterpart of a joint-stock company. As the first multinational type of company, it should bring 
a number of benefits to entrepreneurs. This concerns in particular the possibility of the transfer without complications, and the possibility to carry out a cross-border merger is among the most important. European society is also seen as a symbol of a united Europe (Patakyová et al., 2020).

However, European society is not an instrument that fits the specific nature of cooperatives. Nor does the European Economic Interest Grouping meet the specific requirements of entrepreneurship in the legal form of cooperatives. The current European Community policy aims to create appropriate legal instruments to facilitate the development of the cross-border activity of cooperatives as a result of efforts to ensure a level playing field and efforts to develop their economic development. Cooperatives, unlike companies, are primarily communities of natural or legal persons with specific operating principles which differ from those of other economic operators (Prokopenko et al., 2015). These principles primarily include the principles of democratic structure and control and a fair distribution of net profit for the financial year. These principles include, in particular, the principle of primacy of a personal element over capital, which is reflected in the special rules on admission as a member of a cooperative, withdrawing from the cooperative and excluding a member of the cooperative, where the 'one member, one vote' rule applies, with the right to vote linked to a person, while at the same time the members of the cooperative may not exercise any rights to the assets of the cooperative. Cooperatives have equity capital on members' contributions and their members may be natural or legal persons. These members may, in whole or in part, be the customers, employees or suppliers of the cooperative. If the cooperative is made up of members having the legal form of a cooperative, it is a 'secondary' or 'second-level' cooperative.

In general, entrepreneurship in the form of a European company and a European cooperative does not meet the presumed interest of entrepreneurs in the Slovak Republic. In our view, their lack of interest, as well as the vagueness and fragmentation of the rules, may result in the lack of interest in economics theorists and the law to examine this issue further, despite its undoubted importance in economic practice. That is why we decided to comprehensively examine the regulation of European society and the European cooperative from the point of view of valid and effective not only European but also Slovak legislation. Our intention is also in line with the structure of the article, which is divided into two chapters, the first of which comprehensively examines European society and the second examines European cooperative. 


\section{Theoretical background}

The idea of a European company, Latin 'Societa Europaea', the abbreviation 'SE', as a transnational European counterpart of a public limited company, came into practice only by the adoption of Council Regulation (EC) No 2157/2001 of 8 October 2001 on the Statute for a European Company. Together with Council Directive 2001/86/EC of 8 October 2001, they constitute the basic legal framework for the regulation and status of a European company, which, for the most part, is determined by the law of the State in which its registered office is located. The primary Slovak law governing the status of European companies established in the territory of the Slovak Republic is Act No. 562/2004 Coll. on European Company, as amended (hereinafter referred to as the European Company Act).In cases directly regulated by a European regulation, the application of national Slovak law is directly excluded, while our law cannot regulate the problems chosen in a way different from the Regulation. According to Funta (2018) the European Company Law does not deal with issues directly regulated by the Regulation, but only addresses issues that are left to national law as a rule of law. However, as Nosková (2019) states by amending national legislation, it ensures that our national legislation complies with the various provisions of the Regulation. As part of the investigation of a European company, he considers it necessary, first of all, to draw attention to the fact that it is a parallel to our joint-stock company.

Unlike it, however, it offers a number of advantages that make it at least and at first glance an interesting alternative in choosing the appropriate form for newly emerging companies. Above all, the purpose of European society is to facilitate the free movement of capital throughout the European Union and to unite company legal forms. If the company contains the abbreviation "SE" in the name, there will be no further need to examine whether this form of company provides a sufficient sense of security for business partners. As it adds Šlahor (2016) another important objective of creation was also the possibility of competing with large American and Japanese corporations and, for this reason, one of the main priorities was to create the conditions for the European Union to become the most competitive economy in the world. As Nováčková et al. (2018) states another benefit is saving up to 30 billion euros per year on administrative and other costs. The purpose is therefore mainly to remove obstacles to entrepreneurship resulting from differences in company regulations in different member states and from the existence of national boundaries for companies and people operating internationally. 
Economic development, in particular through cross-border cooperation between cooperatives in the territory of the European Union, primarily hampered both legal and administrative obstacles. It was therefore necessary, according to Švec and Madleňák (2017) the basic objective of Council Regulation (EC) No 1435/2003 of 22 July 2003 on the Statute for a European Cooperative Society is therefore to enable natural persons residing in different Member States or legal persons established under the laws of different Member States to form a European cooperative. As Nosková (2020) it is a precondition for this cooperative to have its registered office and its head office in one Member State and an establishment or subsidiary in another Member State. As it adds Bazen and Duma (2019) References to capital in Council Regulation (EC) No 1435/2003 of 22 July 2003 on the Statute for a European Cooperative Society shall apply exclusively to capital. According to Kryvinska et al. (2020) and Prokopenko et al. (2015), the regulation also does not regulate other legal areas such as taxation, competition or insolvency. Therefore, in these areas and in other areas, only the laws of the Member States as well as European Community law apply. In accordance with Dudic at al. (2020) its capital shall be divided into members' contributions, the number of members and the amount of the capital of the European cooperative being variable.

According to Chehabeddine and Tvaronavičiene (2020) as regards the liability of the members of the cooperative if all members of the European cooperative have limited liability, the commercial name of the European Cooperative Society shall include an addendum 'with limited liability'. According to the scientific literature, the European cooperative's business can, in particular, be used to meet the needs of its members by encouraging their participation in economic activity. What should be emphasised, however, is that a European cooperative must not extend the benefits of its activities to non-members, but in particular it must not allow them to participate in such activities. Applying the principle of dissimilarity Funta (2018) the implementing Slovak law governing the legal status of a European cooperative established in the territory of the Slovak Republic is Act No. 91/2007 Coll. on the European Cooperative Society, as amended (hereinafter referred to as the European Cooperative Society Act).

\section{Objective and methodology}

The main objective of the article is to comprehensively analyse the legislative aspects of the European society and the European cooperative and to examine their legal regulation and status 
in the legal system of the Slovak Republic. In addition to the main objective, we have also chosen two milestones:

1. verify the assumption that the European company and the European cooperative represent prospective legal forms of business in the conditions of the Slovak Republic,

2. assess the rules of the two entities and, where appropriate, make proposals "de lege ferenda".

We want to achieve our stated objectives, particularly through thorough study of legislation, scientific and scientific literature, as well as jurisprudence. Due to the nature of the scientific article, we use a number of scientific methods of knowledge suitable for the knowledge of the law. This concerns, in particular, the use of critical analysis to review the legal and regulatory situation as well as abstractions. By applying a comparative method, we make different views of economists and lawyers available not only on the appropriateness of regulation but also on the interpretation of individual legal institutes. In this way we strive for multidisciplinary scrutiny. Due to our own years of experience in the practice of law in the field of commercial law, we also use doctrinal interpretation. Selected legislation of European and Slovak law is an essential source of knowledge needed to achieve the main objective. According to us, the case law of Slovak courts is appropriately and meaningfully complemented by the aim of harmonising the interpretation of disputed legal institutes. Special and not less important place belongs to scientific and professional literature.

\section{Results and Discussion}

\section{European joint-stock company}

Slovak legislature European company as a legal person registered in the State of its registered office, and its registration and erasure is compulsory in the Official Journal of the European Union. In terms of company type, it is a capital company whose capital consists of contributions from shareholders divided into shares. While a commercial company is liable for its liabilities with all its assets, shareholders are liable for the liabilities of the company only up to the amount of their shares. Here we point out that while the capital of a public limited company is "only" EUR 25 thousand, the capital of the European company must be at least 120 thousand Euros, and can be expressed only in euros. However, save as otherwise provided in the Regulation, the capital of the European company, its maintenance and amendments, together with the shares 
and other securities, shall be governed by the laws which would apply to a public limited company established in the Member State in which the European company is incorporated. According to Štefko (2019) he shares this view Dul'ová - Spišáková et al. (2017) the possible derogation applies only to legal persons who have an abbreviation 'SE' in their business name or other designation, provided that they arose before the date of entry into force of the Regulation.

As stated in the specialised literature Bobenič Hintošová et al. (2020) the founding document of European society is the Statutes. The Regulation provides that a company is required to place its head office in the same Member State where the European company has its registered office. However, a company with its head office outside the territory of the European Union or another Contracting State of the European Economic Community may participate in its establishment in the territory of the Slovak Republic under certain conditions. In principle, however, according to Melovic et al. (2020) however, attention must be drawn here to the fact that European society cannot be founded in a successive manner and, except for an exception, cannot be established in a simultaneous way. In our view, this means, in practice, that it cannot be based on the mere subscription of shares, because it is a legal form primarily intended for more capitalintensive forms of business.

The key issue that we consider necessary to focus on is the way in which European society is founded. It is primarily a merger - a merger. The merger shall be the case of at least two public limited liability companies subject to the law of the different Member States of the European Union having their registered office and their head office in its territory. The company formed may also have its registered office in the territory of a third Member State. This is currently the most widespread way of establishing European society. Another, rather frequent way of setting up a European company is holding. However Patakyová et al. 2020 points out, however, that the establishment of a holding company by at least two capital companies, where they are governed by the law of another Member State or have at least two years of subsidiary or branch located in another Member State, are governed by the law of another Member State. The founding companies thus become subsidiaries of the newly created European company. The third, but not according to Sararu (2008) in practice, it is the creation of a subsidiary by subscriptions of shares by companies governed by the law of different Member States. The fourth option is to change the legal form by transforming a public limited liability company established under the law of a Member State. In practice it will be a situation where, for example, the Polish joint-stock company had a subsidiary 
in Slovakia for at least 2 years, after the transformation it could become a European company. The last possible way is to establish a subsidiary of another European company. As he argues it also points out, however, that today, the easiest way to establish a European company in the form of a ready-made company can be considered to be the easiest way of establishing a European company, in particular because of the lengthy and overly complicated set-up process.

\section{Governance and dissolution of European society}

In the management of European society, legislation recognises the possibility of choosing from two different forms of internal structure. Such a decision, however, according to case law (Supreme Court of the Slovak Republic No. 5Obdo 11/2010) belongs only to the exclusive competence of the founders, who will determine their form, especially from the point of view that is more advantageous to them. From an internal governance perspective, European society can have two forms of governance. The first is a two-tier (dualistic) system that recognises the management body and the supervisory authority as two separate bodies of the company. This system is commonly known from already existing Slovak public limited companies, where the governing body is the Board of Directors and the supervisory authority is the Supervisory Board.

Here again, the incompatibility of functions applies, which means in practice that the function of a member of the board of directors is incompatible with membership of the Board of Supervisors and vice versa. However, the advantage of this system is the separation of management and control, and the Supervisory Board becomes a good representative of the company's shareholders.

The one-stage (monistic) management system according to Macíková et al. (2018) in this case, the company is headed by a board of directors headed by the chairman. The main advantage of this form is to speed up decision-making processes, lower costs and simplify the system for smaller businesses.

From the point of view of personnel management, attention should also be drawn to the regulation, which directly guarantees the protection of employees. This concerns, in particular, the merger of companies as well as the conversion of a joint-stock company into a European company. The rights and obligations of the participating companies with regard to employment issues that existed at the date of registration of the European company shall pass on the date of registration. Unlike the Slovak public limited company, however, a specific element of the European company is mandatory employee participation in its management. This also plays an important role in the 
very process of establishing this type of company, as it is not possible to set up this company without resolving this issue. Halasi et al. (2019) shall stress that employees' rights in the management of a European company are exhaustively established, including in particular the right to information and consultation, as well as the right to vote and to stand as a candidate, or to express consent or disagreement with the election or appointment of members of the board of directors or supervisory board of a European company. According to the Supreme Court of the Slovak Republic (1 Odo 47/2018) we believe that its purpose is to guarantee employees the right to be involved in matters and decisions affecting the life of their European society. However, other social and labour law issues, in particular the right of employees to information and consultation, as provided for in the Member States, are already governed by national legislation applied under the same conditions for public limited liability companies.

Selected procedures for resolving winding-up problems, winding-up shall be governed by the law of the Member State which would govern the company under the law of the Member State of the registered office of the European company. This is also true in the decision-making process at the shareholders' general meeting as stated Duma (2016).

\section{European Cooperative Society}

The establishment of a European cooperative is generally governed by the law applicable to cooperatives in the Member State of the future seat of the European cooperative. What is understood by the 'founding' process, however, has been dealt with more closely in the section on European society. Indeed, according to Srebalová et al. (2020) the establishment concerns, in particular, the question of compliance of the statutes with the law of the State of the seat of the European Cooperative Society. The registration of a European company shall be published in the Commercial Journal by an entry notice. However, the European Cooperative Society shall acquire legal personality on the day of its entry in the Member State of establishment in the register designated by that State. It is therefore compatible with its law on public limited liability companies. As with European society, the European cooperative can be established in 5 ways. First, five or more natural persons residing in at least two Member States. The second option is the establishment by five or more natural persons and companies or cooperatives established under the law of a Member State, resident or established in at least two different Member States or governed by the law of at least two Member States. The possibility of setting up companies or 
cooperatives governed by the law of at least two Member States is also considered. The penultimate option is the merger of cooperatives established under the law of a Member State with their registered offices and headquarters in the Community. However, this is only possible provided that at least two of them are governed by the law of different Member States. Prokopenko et al. (2014) considers that the last possibility is to change the legal form of a cooperative established under the law of a Member State having its registered office and head office in the territory of the European Community. However, it shall be a condition for a branch or a subsidiary governed by the law of another Member State to operate for at least two years.

The capital of the European Cooperative Society shall be expressed in national currency, the minimum amount of which must exceed 30 thousand Euro. However, the establishment of the cooperative shall also determine the amount below which the capital cannot be reduced as a result of the payment of the compensatory shares to members who have ceased to be members of the European Cooperative Society.

\section{Acquisition and termination of membership}

Not only natural persons but also legal persons may become members of a European cooperative, provided that the statutes do not specify otherwise. Except in the case of the merger of cooperatives, where the members of the acquired cooperative become members of the acquiring European cooperative as the effect of the merger, the creation of a membership of a European cooperative shall be subject to the consent of the management or administrative body. The refusal of membership may be subject to an appeal to a member meeting which takes place after an application for membership has been lodged. However, the acquisition of such membership, in the opinion of the Supreme Court of the Slovak Republic 7 Obdo 69/2009 who are legal persons shall be deemed to participate in the activities of the European Cooperative Society by representing their own members.

As he warns Šimonová et al. (2019) even in the event of the disappearance of membership in the cooperative, we see several similarities with the commercial law of the classical cooperative in the Slovak Act No. 513/1991 Coll. The Commercial Code. Membership expires by withdrawal, cancellation in case of a member who is not a natural person, bankruptcy or death. Exclusion can only be considered because of serious breaches of Member States' obligations or actions contrary to the interests of the European cooperative. The transfer of membership rights to another member 
or other natural or legal person who has acquired membership is also the reason for the termination. According to the decision of the Supreme Court of the Slovak Republic no 13 Obo 87/2011 in the event of an extension of the period of notice to more than five years, membership shall cease on expiry of the period running from the notification which was in force prior to the amendment of the Statutes.

\section{Structure of the European Cooperative Society}

There is also a clear impact of European policy on the governance of a European cooperative, when the legislature accepts two models. The first is the dual management method carried out by the membership meeting, the supervisory body and the managing authority. The managing authority shall be directly responsible for the management of the European cooperative and represent it in proceedings with third parties as well as in proceedings before the courts. It is an original jurisdiction which, according to Groeneveld (2020) can not be revoked by decision of the membership meeting. However, the legislation of a Member State may, by way of derogation, provide that the Executive Director is responsible for day-to-day management under the same conditions as for cooperatives established in the territory of that State. The member or members of the management body shall be appointed and dismissed by the supervisory body, not by the membership meeting but by the body. In the context of the incompatibility of the function, the principle of non-cumulation of function shall be applied. This means, in practice, that a member of the management body must not be a member of the supervisory body of the same European cooperative at the same time. However, the supervisory authority may appoint one of its members to act as a member of the management body. However, according to Havierniková et al. (2017) during this period, such a person shall be suspended from his duties in the supervisory authority. The managing authority shall elect, in accordance with the Statutes, a Chairperson from its members, who shall convene a meeting of the Management Authority under the conditions laid down in the Statutes, either on its own initiative or at the request of any member. However, any such request shall state the reasons for the convening of a meeting on a mandatory basis.

As further points out Markovic (2003) in addition to that regular information, the legislature has imperatively expressed the obligation of the managing authority to communicate without delay to the supervisory authority all information on events which could have a significant impact on the European cooperative. As in the case of the management body, the election of the 
Chairperson of the Supervisory Body shall be entrusted to its members, who shall elect their Chairperson. If half of the members are elected by staff, only the member elected by the member's meeting may be elected president. The Chairperson shall convene a meeting of the supervisory authority, under the conditions laid down in the Statutes, at his initiative or at the request of at least one third of the members of the supervisory authority, or at the request of the managing authority.

Žulová and Kundrát (2020) emphasises that the dualist model allows the law of a Member State to provide that the supervisory authority may itself determine which types of action require its approval. However, the law of the Slovak Republic entrusted such powers to the Control Commission. The scientific literature (Nosková, 2020) points out that in the Monistic model for European cooperatives, this is not directly regulated by the regulation and does not make any direct reference to the possibility of national legislation. Within the framework of the management of the European company as well as the European cooperative in the Monistic model, the Slovak legislation allows the Board to reserve its approval also for decisions of executive directors, for which their statutes do not confer such competence.

In the monistic model of governance, it is a "administrative body" which manages the European cooperative and represents it in proceedings with third parties and in proceedings before courts or other bodies. A Member State may only designate the Executive Director to be responsible for normal management under the same conditions as in the case of cooperatives established in the territory of that Member State. The number of members of the administrative body or the rules for its designation shall be determined by the statutes. The Member State has been entrusted with the discretion to set a minimum and, if necessary, a maximum number. However, unlike the European Union, the Slovak legislation directly prohibits the participation of legal persons on the board of directors, which has at least three members, if employee participation is regulated pursuant to Commission Directive 2003/72/EC. Members of the administrative body and, where the statutes so provide, their alternates shall be elected by a member's meeting. The members of the first administrative body may be designated in the statutes. This is without prejudice to agreements on employee involvement. A Member State may therefore not take appropriate measures in relation to a European cooperative if the monetary model in relation to cooperatives established on its territory is not adapted. In this context, the Slovak law on the European Cooperative provides that the Board of Directors, in addition to managing a European 
cooperative, decides on all its matters in which the competence of a member meeting or executive directors is not defined. Here, in our view, only the business management and the implementing law are likely to remain entrusted with the powers conferred on them. However, even on this issue Mucha (2019), it is convinced that the Management Board can reserve its agreement to those decisions of the Executive Directors for which this consent is not required by the Statute for a European Cooperative Society. It is therefore the same as that of European society.

The administrative body must meet at intervals governed by the Statutes, but at least every three months, to discuss the progress and foreseeable development of the business of the European Cooperative Society. In this case, too, the rule is to take into account, where appropriate, all information relating to undertakings controlled by a European cooperative which may significantly affect its further business or activity. Sararu (2014) in particular he focuses his attention on the length of his term of office. It considers that the members of the bodies of the European Cooperative Society may be elected only for the period specified in the Statutes, which must not exceed six years. If the Statutes do not impose other restrictions, the members of the bodies of the European Cooperative Society may also be elected again for a term of office specified by the Statutes. However, this must not exceed six years.

\section{Distribution of profits}

Despite the fact that a European cooperative does not have to be mandatory for the purpose of making a profit, the statutes must determine the rules governing the use of the net profit for each financial year. However, this in no way affects the mandatory provisions of national law under Mariš (2016) the statutes, without exception, under the threat of nullity, always provide for the need to set up a reserve fund in order to achieve net profit. Until the minimum capital of EUR 30 thousand has been reached, the allocation to the reserve may never be less than $15 \%$ of the amount of net profit for the financial year less losses from previous years, which is followed by economic literature (Mariš, 2019)

Members of a European cooperative whose membership of the European cooperative ceases to exist, the legislature has withdrawn their entitlement to the resources allocated to the reserve fund. However, the articles of association may stipulate that the members shall share profits through a dividend in proportion to their participation in the business of a European cooperative or in proportion to the activities carried out for the European cooperative. The 
available net profit, which is possible, but not necessarily distributed among the members of the cooperative, is the balance of the net profit reduced by the allocation not only to the statutory reserve fund, but also by, for example, amounts paid as dividends or unpaid losses from past periods.

Winding-up, winding-up, insolvency, suspension of payments and similar procedures

The procedures for resolving winding-up, winding-up, insolvency or suspension procedures shall be governed by the law of a Member State governing the cooperative under the law of the Member State of establishment of the European Cooperative Society. This also applies to the adjustment of decision-making at the membership meeting. At the request of the person who demonstrates a legitimate interest, or at the request of the competent authority, the court or other competent administrative authority of the Member State of establishment shall decide to cancel the European Cooperative Society if it finds an infringement, for example, in its formation procedure, the determination of the amount of the capital

The court or the competent administrative authority may, however, impose a time limit on the European Cooperative Society before the decision on revocation. If the European Cooperative Society does not recover within the time limit thus determined, the court or the competent administrative body shall decide to cancel it. The same procedure applies in the event that the European cooperative ceases to meet the requirements of the established registered office and head office in the same country. The Member State of establishment of the European Cooperative Society shall take the necessary measures to ensure the liquidation of a European cooperative which does not eliminate the illegal situation under the Regulation. However, it will ensure, through its legislation, the possibility of reviewing or lodging an appeal against a decision declaring an infringement of the Directive and the Regulation. Under the terms of the Slovak Republic, this obligation was implemented by amending Act No. 513/1991 Coll. The Commercial Code. The lodging of an appeal as an appeal against a court decision on the winding-up of the European Cooperative Society has a suspensive effect on the expiry of the time limit for the removal of the irregularity as well as on the winding-up procedure itself.

The commencement and termination of proceedings for the winding-up of the European Cooperative Society, including the voluntary winding-up, commencement and termination of the insolvency proceedings or other similar proceedings, as well as any decision to continue the 
business of the European Cooperative Society, shall be published in the Commercial Journal by publication of a notice therein, without prejudice to the provisions of national law which require further disclosure.

In these cases, the net commercial assets shall be distributed in accordance with the principle of impartial distribution, which in practice means their transfer to another entity organised in the legal form of a cooperative which pursues similar objectives or serves the general interest. The second possibility is, however, if the law of the Member State of establishment of the European Cooperative Society allows it to apply Paragraph 259(3) of the Commercial Code by analogy. Such Slovak legislation directly provides for the distribution of the balance of the winding-up balance among the members in the manner laid down in the statutes.

\section{Conclusion}

The present article focused on a critical analysis of the legal aspects of European society and the European cooperative. In our view, we have been advised to meet the objectives set. By examining these transnational legal forms of entrepreneurship, we have identified a number of disadvantages in particular. The first is the impossibility of a European company in a form other than a public limited company. It is equally problematic that a natural person cannot establish a European society or be one of its founders. Furthermore, it would be reasonable, in our view, to assume that a European company, as a multinational legal form of companies, will be able to operate smoothly throughout the European Union. This is not true, however, because it has to establish itself in other Member States where it wants to do business. This is considered to be a separate undertaking, which must keep separate accounts and also pay taxes. In practice, this means that entrepreneurs can only do business in their parent country and, if they are interested in doing business in another Member State, have to set up another business entity (which is essentially an establishment).Thus, European society does not allow the direct entrepreneurship of a single business entity in several Member States of the European Union. We would be able to solve such a problem by amending the legislation that would enable entrepreneurship in all the Member States of the Union without the need to set up organisational units in the individual Member States. In the other countries of the European Union, the European company would only carry out its business by opening up establishments. However, what should be emphasised is the economic side of the operation, which translates into increased transaction costs and the need for adaptation in 
the State of the new premises. Not only the European company and the European cooperative are subject to the legal regime of the selected country, whether all documents must be delivered to the registered office abroad and any future litigation will be settled at the place of establishment of the company or cooperative.

Another problem, particularly related to the establishment of a European society as well as cooperatives, is the lack of a single register of European companies and cooperatives. This objectively causes problems in the selection of a business name, with which further complications may arise in the change of registered office. Since individual business registers of Member States do not cooperate with each other or are not expected to be interconnected, there may be a situation in which several European companies or European cooperatives with the same business name will be established in several Member States. We consider a further disadvantage to European society and the European cooperative to be very high capital, and this certainly discourages small and medium-sized entrepreneurs in particular from choosing the legal form of doing business. A significant disadvantage for European society is also its impossibility of establishing a natural person, as it is primarily intended for large entrepreneurs. However, the legislature did not take into account the fact that, even within the European Union, it is small and medium-sized entrepreneurs who make up a substantial part of the business sector.

The European joint-stock company as well as the European cooperative are no longer new, but still unknown in public perception of legal forms of business. The European society and the European cooperative, as legal forms of business, bring a number of seeming advantages. However, they do not bring sufficient real benefits to entrepreneurs compared to other legal forms. In no way do they facilitate entrepreneurship in the European Economic Area compared to other legal forms. It is possible to agree with the opinions that the European public limited company as well as the European cooperative is only "undone the work of European officials." In essence, it is only a worthless "legislative symbol of the unification of the European Union" Even after more than 15 years of existence in the current state it has no benefit for Slovak entrepreneurs, which is reflected in the absence of these legal forms of business in the annual statistics of established and extinct business entities in the Slovak Republic. For this reason, we do not consider it necessary to deal with 'de lege ferenda' proposals which would significantly improve their legislation. In conclusion, therefore, the European company and the European cooperative do not represent prospective legal forms of business under the conditions of the Slovak Republic. 


\section{Acknowledgement}

This article represents a partial result of the project "1/0813/19 Managing the development of innovative and start-up forms of businesses in international environment and verification of INMARK concept."

\section{References}

1. Bazen, J. \& Duma, F. (2019). Role of international educational projects in supporting European integration in the context of Romania. Online Journal Modelling the New Europe, (30), pp. 65-77, doi: 10.24193/OJMNE.2019.30.04

2. Bobenič Hintošová, A., Bobenič, T., Hajduová, Z. \& Szajt, M. (2020). The influence of firm-specific factors on firms' performance [Wpływ czynników specyficznych dla firmy na jej wyniki]. Polish Journal of Management Studies, 21 (2), pp. 115-128, doi: 10.17512/pjms.2020.21.2.09

3. Chehabeddine, M. \& Tvaronavičiené, M. (2020). Securing regional development. Insights into Regional Development 2 (1), pp. 430-442. doi: 10.9770/IRD.2020.2.1(3)

4. Council of the European Communities. (2001). Regulation no. 2157/2001 on the Statute for a European company. Retrieved August 15, 2020 from: https://eur-lex.europa.eu/legalcontent/SK/LSU/?uri=celex:32001R2157

5. Council of the European Communities. (2003). Regulation no. 1435/2003 on the Statute for a European Cooperative Society. Retrieved August 15, 2020 from: https://eurlex.europa.eu/legal-content/SK/TXT/?uri=celex\%3A32003R1435

6. Dudić, Z., Dudić, B. \& Agbaba, B. (2020). Analysis of the European Social Charter and its importance for the protection of selected groups of working women. Central European Journal of Labour Law and Personnel Management, 3 (1), pp. 7-20, doi: 10.33382/cejllpm.2020.04.01

7. Duma, F.S. (2016). Integration of the stock markets from the European Union. A convergent or a divergent process? Online Journal Modelling the New Europe, 19 (1), pp. $18-28$ 
8. Dul'ová Spišáková, E., Mura, L., Gontkovičová, B. \& Hajduová, Z. (2017). R\&D in the context of Europe 2020 in selected countries. Economic Computation and Economic Cybernetics Studies and Research, 51 (4), pp. 243-261

9. European Commission. (2019). Real GDP growth rate - volume. Retrieved May 28, 2020 from: https://ec.europa.eu/eurostat/tgm/table.do?tab=table\&plugin= $1 \&$ language=en $\underline{\text { \&pcode }}=\mathrm{tec} 00115$

10. Federal Assembly of the Czech and Slovak Federal Republic. (1991). Act no. 513/1991 Coll. Commercial Code. Retrieved August 10, 2020 from: https://www.slov-lex.sk/pravnepredpisy/SK/ZZ/1991/513/20200721

11. Funta, R. (2018). Extraterritorial application of us-antitrust law on global cartels from comparative (EU LAW) perspective. Lawyer Quarterly, 8 (3), pp. 214-223

12. Groeneveld, H. (2020). Reconciling different truths about isomorphic pressure and distinctive behavior at European cooperative banks: Back to the future with Raiffeisen's principles. Annals of Public and Cooperative Economics, 91 (3), pp. 359-386

13. Halasi, D., Schwarcz, P., Mura, L. \& Roháčiková, O. (2019). The impact of EU support resources on business success of family-owned businesses. Potravinarstvo Slovak Journal of Food Sciences, 13 (1), pp. 846-853. doi:10.5219/1167

14. Havierniková, K., Lemańska-Majdzik, A. \& Mura, L. (2017). Advantages and Disadvantages of the Participation of SMEs in Tourism Clusters. Journal of Environmental Management and Tourism, 8 (6), pp. 1205-1215, doi: 10.14505/jemt.v8.6(22).07

15. Kryvinska, N., Kaczor, S. \& Strauss, C. (2020). Enterprises' servitization in the first decade-retrospective analysis of back-end and front-end challenges. Applied Sciences, 10 (8), 2957, doi: 10.3390/APP10082957

16. Maciková, L., Smorada, M., Dorčák, P., Beug, B. \& Markovič, P. (2018). Financial aspects of sustainability: An evidence from Slovak companies. Sustainability, 10 (7), 2274, doi: $10.3390 /$ su 10072274

17. Mariš, M. (2016). Effects of the centrifugal and centripetal effects in core versus (semi)periphery in Central Europe countries. Acta Universitatis Agriculturae et Silviculturae Mendelianae Brunensis, 64 (3), pp. 993 - 100. doi: 10.11118/actaun201664030993 
18. Mariš, M. (2019). Structural and productivity shift of industries in Slovakia and Czech Republic: A comparative study. Journal of International Studies, 12 (1), pp. 313-323, doi: $10.14254 / 2071-8330.2019 / 12-1 / 21$

19. Markovič, P. (2003). Determining the fair value of the derivates contracts [Stanovenie reálnej hodnoty derivátových kontraktov]. Ekonomicky casopis, 51 (9), pp. 1113-1126

20. Melović, B., Jocović, M., Dabić, M., Vulić, T.B. \& Dudic, B. (2020). The impact of digital transformation and digital marketing on the brand promotion, positioning and electronic business in Montenegro. Technology in Society, 63, Article nr. 101425, doi: 10.1016/j.techsoc.2020.101425

21. Mucha, B. (2019). Tools to increase the effectiveness of comprehensive management of emergencies affected by climate change in the Slovak Republic. International Multidisciplinary Scientific GeoConference Surveying Geology and Mining Ecology Management, SGEM. 19 (5.4), pp. 573-580, doi: 10.5593/sgem2019/5.4/S23.075

22. Mura, L., Gontkovicova, B., Spisakova, E.D. \& Hajduova, Z. (2019). Position of employee benefits in remuneration structure. Transformation in Business and Economics, 18, (2), pp. 156-173,

23. National Council of the Slovak Republic. (2004). Act no. 562/2004 Coll. about European society. Retrieved August 15, 2020 from: https://www.slov-lex.sk/pravnepredpisy/SK/ZZ/2004/562/20091201

24. National Council of the Slovak Republic. (2007). Act no. 91/2007 Coll. on the European Cooperative Society. Retrieved August 15, 2020 https://www.slov-lex.sk/pravnepredpisy/SK/ZZ/2007/91/20070401

25. Noskova, M. (2019). International Business law. Bratislava: Comenius University

26. Noskova, M. (2020). Compliance management. Bratislava: Comenius University

27. Novackova, D., Paškrtova, L. \& Saxunová, D. (2018). Investment aid as a catholicon for regional development in Slovakia? International Journal of Economic Policy in Emerging Economies, 11 (3), pp. 209-227, doi: 10.1504/IJEPEE.2018.093949

28. Patakyová, M., Kačaljak, M., Grambličková, B., Mazúr, J. \& Dutková, P. (2020). Slovak Simple Joint Stock Company - Critical Review and Preliminary Assessment. European Company and Financial Law Review, 17 (2), pp. 205-230, doi: 10.1515/ecfr-2020-0011 
29. Prokopenko, O., Kudrina, O. \& Omelyanenko, V. (2015). Analysis of ICT Application in Technology Transfer Management within Industry 4.0 Conditions (Education Based Approach). CEUR Workshop Proceedings, pp. 258-273.

30. Prokopenko, O., Kysly, V. \& Shevchenko, H. (2014). Peculiarities of the natural resources economic estimation under the transformational conditions. Economic Annals-XXI, 7-8, pp. 40-43.

31. Sararu, C. S. (2008). Consideraţii cu privire la limitele libertătii contractuale în dreptul public impuse de integrarea în uniunea europeană. Transylvanian Review of Administrative Sciences, 1, pp. 131-140

32. Sararu, C. S. (2014). The European Groupings of Territorial Cooperation developed by administrative structures in Romania and Hungary. Acta Juridica Hungarica, 55 (2), pp. 150-162, doi: 10.1556/AJur.55.2014.2.5

33. Šlahor, L. (2016). VAT evasion: Recent evidence from Slovakia. Proceedings of the 26th International Business Information Management Association Conference - Innovation Management and Sustainable Economic Competitive Advantage: From Regional Development to Global Growth, IBIMA 2015, pp. 1555-1560

34. Srebalová, M., Horvat, M., Vačok, J., Vojtech, F. \& Filip, S. (2020). Legal obstacles to freedom to conduct a business: experience of the Slovak Republic, Entrepreneurship and Sustainability Issues, 7 (4), pp. 3385-3394. doi: 10.9770/jesi.2020.7.4(53)

35. Supreme Court of the Slovak Republic. (2011). Judgement Nr. 13 Obo 87/2011

36. Supreme Court of the Slovak Republic. (2009). Judgement Nr. 7 Obdo 69/2009

37. Supreme Court of the Slovak Republic. (2018). Judgement Nr. 1 Obdo 47/2018

38. Supreme Court of the Slovak Republic. (2010). Judgement Nr. 5 Obdo 112010

39. Štefko, M. (2019). Notice for reasons of redundancy as a measure for discrimination on grounds of age. Central European Journal of Labour Law and Personnel Management, 1 (1), pp. 61-73. doi: 10.33382/cejllpm.2019.02.05

40. Švec, M. \& Madleňák, A. (2017). Legal frameworks for the phygital concept. European Journal of Science and Theology, 13 (6), pp. 209-217

41. Žul'ová, J. \& Kundrát, I. (2020). Service of documents in employment relationships during the employee quarantine. Central European Journal of Labor Law and Personnel Management, 3 (1), pp. 74-84. doi: 10.33382/cejllpm.2020.04.06 